\title{
ORANG YANG MEWARISKAN HARTANYA DALAM \\ PERSPEKTIF KOMPILASI HUKUM ISLAM
}

\begin{abstract}
Naskur
ABSTRAK

Orang yang mewariskan hartanya adalah orang yang telah meninggal dunia dengan bentuk kematian secara hakiki, hukmy dan taqdiri. Kematian secara hakiki atau dalam Kompilasi Hukum Islam disebutkan orang yang pada saat meninggal adalah kematian tanpa melalui pembuktian dapat diketahui dan dinyatakan bahwa seseorang telah meninggal dunia. Kematian secara yuridis atau dalam Kompilasi Hukum Islam yang dinyatakan meninggal adalah dimaksudkan kematian melalui keputusan hakim dinyatakan telah meninggal dunia. Sedangkan kematian secara taqdiri yang dalam Kompilasi Hukum Islam termasuk dalam kategori orang yang dinyatakan meninggal adalah kematian yang berdasarkan anggapan bahwa seseorang telah meninggal dunia.
\end{abstract}

Kata kunci: Pewaris, Meninggal dunia, Kompilasi Hukum Islam

\section{A. PENDAHULUAN}

Pelaksanaan hukum kewarisan Islam di Indonesia telah diadakan pengaturan kembali yang disusun dalam bentuk Kompilasi Hukum Islam (KHI). Pengaturan kembali hukum kewarisan Islam di Indonesia adalah erat sekali hubungannya dengan munculnya berbagai gagasan tentang pembaruan pemikiran hukum Islam. Hal ini dilakukan karena hukum Islam dianggap tidak relevan lagi dengan perkembangan dan kemajuan kehidupan sosial masyarakat. Dalam hal ini termasuk hukum kewarisan Islam menjadi agenda pemikiran untuk melaksanakan pemabaruan. Pembaruan yang dilakukan pada hukum kewarisan adalah dimaksudkan untuk memodifikasi terhadap ketentuan yang telah diatur dalam AlQur'an maupun dalam Al-Hadits dengan cara mengaktualkan dalam kehidupan sosial masyarakat Islam yang ada di Indonesia. 
Dalam kaitannya dengan orang yang mewariskan hartanya kepada ahli warisnya, Kompilasi Hukum Kewarisan Islam (KHI) merumuskan kembali pengertian orang yang mewariskan hartanya (pewaris) dan menetapkan syaratsyaratnya sehingga orang yang akan mewariskan hartanya disebut sebagai pewaris.

\section{PEWARIS DALAM KOMPILASI HUKUM ISLAM}

1. Telah meninggal dunia atau dinyatakan meninggal dunia

Pewaris adalah orang yang mewariskan harta peninggalannya kepada ahli warisnya atau orang yang meninggal dunia dan meninggalkan harta warisan yang dalam kitab-kitab fiqh biasa disebut dengan muwarrits. ${ }^{1}$

Orang mewariskan hartanya (muwarrits) terdapat ketentuan-ketentuan yang harus terpenuhi sebelum harta yang dimiliki diwarisi oleh para ahli warisnya. Hal ini seperti telah diatur dalam Kompilasi Hukum Islam pada pasal pada pasal 171 huruf $b$, sebagai berikut:

Pewaris adalah orang yang pada saat meninggal atau yang dinyatakan meninggal berdasarkan putusan Pengadilan beragama Islam, meninggalkan ahli waris dan harta peninggalan. ${ }^{2}$

Apa yang telah ditetapan dalam Kompilasi Hukum Islam (KHI) berkaitan dengan ketentuan-ketentuan pewaris, adalah tidak menyalahi ketentuan-ketentuan yang telah ditetapkan Allah swt. seperti dijelaskan dalam QS. Al-Nisa'/4: 7 sebagai berikut:

${ }^{1} \mathrm{H}$. Moh. Muhibbin dan H. Abdul Wahid, Hukum Kewarisan Islam: Sebagai Pembaruan Hukum Positif di Indonesia (Cet. I; Jakarta: Sinar Grafika, 2009), h. 60.

${ }^{2} \mathrm{H}$. Zainal Abidin Abubakar, Kumpulan Peraturan Perundang-undangan Dalam Lingkungan Peradilan Agama (Cet. III; Jakarta: Yayasan Al-Hikmah, 1993), h. 348. 


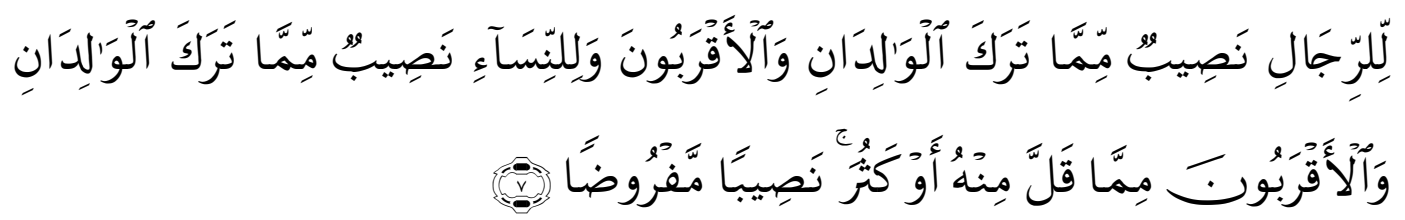

Terjemahnya:

Bagi orang laki-laki ada hak bagian dari harta peninggalan ibu-bapa dan kerabatnya, dan bagi orang wanita ada hak bagian (pula) dari harta peninggalan ibu-bapa dan kerabatnya, baik sedikit atau banyak menurut bahagian yang telah ditetapkan. ${ }^{3}$

Kalimat "bagi orang laki-laki ada hak bagian dari harta pninggalan ibubapa dan kerabatnya dan bagi orang wanita ada hak bagian (pula) dari harta peninggalan ibu-bapa dan kerabatnya", adalah dimaksudkan sesudah kematian ibu-bapa dan keraba. Hal ini sesuai pula dengm Hadis Rasulullah saw. sebagai berikut:

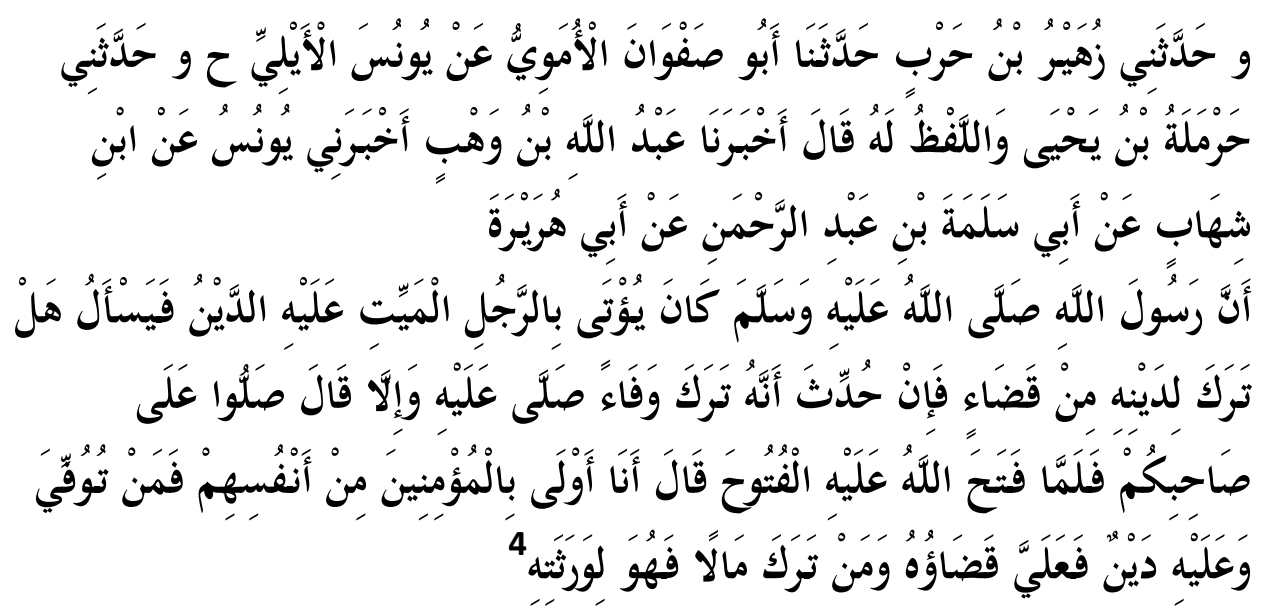

Terjemahnya:

Dan telah menceritakan kepadaku Zuhair bin Harb telah menceritakan kepada kami Abu Shafwan Al Amari dari Yunus Al Aila. (dalam jalur lain disebutkan) Telah menceritakan kepadaku Harmalah bin Yahya dan ini adalah lafadznya, dia berkata, telah mengabarkan kepada kami Abdullah bin Wahb telah mengabarkan kepadaku Yunus dari Ibnu Syihab dari Abu Salamah bin Abdurrahman dari Abu Hurairah, bahwa jenazah seorang lakilaki yang berhutang dibawa ke hadapan Rasulullah shallallahu 'alaihi

${ }^{3}$ Departemen Agama R.I., Al-Qur'an dan Terjemahnya (Jakarta: Yayasan Penyelenggara Penterjemah Al-Qur'an, 1983/1984), h. 116.

${ }^{4}$ Imam Abi al-Husain Muslim ibn al-Hajjaj al-Qusyairy al-Naisabury, Shahih Muslim, Juz. III, (Beirut: Dar al-Kutb al-'Ilmiyyah, t.th.), h. 1237. 
wasallam, beliau bertanya: "Apakah dia meninggalkan sesuatu untuk melunasi hutangnya?", jika dijawab bahwa dia memiliki harta peninggalan untuk melunasi hutangnya, maka beliau menshalatkannya, namun jika dijawab tidak, maka beliau bersabda: 'Shalatkanlah saudara kalian ini." Tatkala Allah menaklukkan berbagai negeri, beliau bersabda: "Aku lebih berhak atas kaum Muslimin dari diri mereka sendiri. Barangsiapa meninggal sedangkan dia masih memiliki tanggungan hutang, maka sayalah yang akan melunasinya. Dan barangsiapa masih meninggalkan harta warisan, maka harta tersebut untuk ahli warisnya.". ${ }^{5}$

Berdasarkan Hadis Rasulullah saw. tersebut, bahwa kematian adalah merupakan syarat mutlak yang harus terpenuhi untuk berpindahnya harta seseorang kepada ahli warisnya. Kematian sebagai syarat terjadinya warismewarisi harus terjadi pada diri seseorang sehingga dapat dikatakan pewaris dan waris-mewarisi dapat berproses.

Amir Syarifuddin menjelaskan bahwa pewaris adalah:

Seseorang yang telah meninggal dunia dan meniggalkan sesuatu yang dapat beralih kepada keluarganya yang masih hidup. Berdasarkan prinsip bahwa peralihan harta dari pewaris kepada ahli waris berlaku sesudah meninggalnya pewaris, maka kata "pewaris" itu sebenarnya tepat untuk pengertian seseorang yang telah mati. ${ }^{6}$

Istilah pewaris itu sendiri mengandung makna dan arti bahwa seorang itu telah meninggal dunia, sebab apabila tidak jelas orang yang memiliki harta itu meninggal atau tidak, maka tidak dapat disebut pewaris.

Idris Djakfar dan Taufik Yahya menjelaskan bahwa:

Meninggalnya pewaris merupakan condition sine quanon untuk terbukanya harta warisan, karena meninggalnya pewaris harus nyata adanya. Apabila tidak jelas kematiannya dan tidak ada pula berita tentang hidupnya, maka

${ }^{5}$ Imam Abi al-Husain Muslim ibn al-Hajjaj al-Qusyairy al-Naisabury, Shahih Muslim, dalam Hadith Ensiklopedi Hadits ver. 1.2 [CD ROM], Lidwa Pusaka, 2010, hadis no. 3040.

\footnotetext{
${ }^{6}$ Amir Syarifuddin, "Kedudukan Anak laki-laki dan Anak Perempuan dalam Hukum Kewarisan", Majalah Orientasi Nomor 2 Tahun VIII. Banjarmasin: Lembaga Perpustakaan/Penerbit Fakultas Hukum Universitas Lambung Mangkurat, h. 51.
} 
hartanya tetap menjadi miliknya yang utuh sebagaimana dalam keadaan yang jelas hidupnya. ${ }^{7}$

Memahami lebih mendalam rumusan pasal 171 huruf b Kompilasi Hukum Islam (KHI), maka orang yang mewariskan hartanyan dengan syarat meninggal dunia mempunyai dua bentuk kematian yaitu kematian dalam bentuk "saat meninggal" dan "yang dinyatakan meninggal berdasarkan putusan Pengadilan". Hal ini sangat berbeda dengan pengertian orang yang mewariskan harta peninggalannya (pewaris) seperti dirumuskan Fatchur Rahman, "yaitu orang yang meninggal dunia, baik mati haqiqi maupun mati hukmy". Sedangkan Ahamd Rofiq merumuskan orang yang akan diwarisi hartanya adalah:

... orang yang diwarisi harta peninggalannya atau orang yang mewariskan hartanya. Syaratnya adalah al-muwarris benar-benar telah meninggal dunia. Apakah meninggal secara hakiki, secara yuridis (hukmy) atau secara taqdiri berdasarkan perkiraan. ${ }^{9}$

Tiga rumusan pengertian orang yang mewariskan hartanya kepada ahli warisnya secara redaksional syaratnya berbeda-beda. Fatchur Rahman menetpakan syarat kematian orang yang mewariskan hartanya kepada dua syarat kematian, yaitu mati haqiqi dan mati hukmy. Ahamd Rofiq menetapkan syarat kematian orang yang mewarisakan hartanya dengan tiga syarat, yaitu meninggal secara hakiki, meninggal secara yuridis dan meninggal secara taqdiri. Sedangkan Kompilasi Hukum Islam (KHI) menetapkan dua syarat, yaitu "saat meninggal" dan "dinyatakan meninggal dunia berdasarkan putusan Pengadilan"

\footnotetext{
${ }^{7}$ Idris Djakfar dan Taufik Yahya, Kompilasi Hukum Kewarisan Islam (Cet. I; Jakarta: PT. Dunia Pustaka Jaya, 1995), h. 52.

${ }^{8}$ Fatchur Rahman, Ilmu Waris (Cet. III; Bandung: PT. Al-Ma'arif, 1994), h. 36.

${ }^{9}$ Ahmad Rofiq, Fiqh Mawaris (Cet. I; Jakarta: PT. RajaGrafindo, 1993), h. 22.
} 
Perbedaan rumusan pengertian orang yang mewariskan hartanya tersebut, syaratnya secara hakiki tidak ada perbedaan. Syarat kematian orang yang mewariskan hartanya menurut Fatchur Rahman dan Ahmad Rofiq, Kompilasi Hukum Islam (KHI) telah merumuskan kembali yang secara hakiki tidak bertentangan dan tidak merubah secara subtansi apa yang dimaksud oleh kedua pakar hukum kewarisan Islam tersebut.

"Saat meninggal" pada rumusan Kompilasi Hukum Islam (KHI) dapat dipahami atau diterjemahkan kepada pengertian mati hakiki. Orang yang saat meninggal dapat dipahami atau diterjemahkan kepada pengertian mati hakiki, karena orang yang saat meninggal pada saat bersama orang lain atau dapat diketahui kemudian setelah meninggalnya dapat diketahui tanpa melalui pembuktian yang harus dinyatakan di hadapan pengadilan. Sedangkan “dinyatakan meninggal dunia berdasarkan putusan Pengadilan" dapat dipahami atau diterjemahkan kepada pengertian mati hukmi dan taqdiri.

Mukti Arto dalam bukunya Hukum Waris Bilateral Dalam Kompilasi Hukum Islam, mengatakan:

Kompilasi Hukum Islam tidak mengenal kematian secara takdiry atau dugaan keras, karena tidak mempunyai kepastian hukum, apabila terdapat keraguanraguan tentang matinya seseorang (termasuk bayi yang masih dalam kandungan ibunya) maka harus diselesaikan dengan putusan hakim, demi kepastian hukum. ${ }^{10}$

Penulis tidak sependapat dengan Mukti Arto yang mengatakan bahwa Kompilasi Hukum Islam tidak mengenal adanya bentuk kematian secara taqdiri dengan alasan karena tidak mempunyai kepastian hukum. Justru karena adanya

\footnotetext{
${ }^{10}$ Mukti Arto, Hukum Kewarisan Bilateral Dalam Kompilasi Hukum Islam (Cet. I; Solo: Balqis Queen, 2009), h. 56.
} 
ketidak pastian tentang kematian seseorang, maka perlu diadakan pembuktian secara hukum sehingga kematiannya dapat dipastikan penyebabnya. Dengan adanya kepastian berdasarkan pembuktian hukum, maka kematian orang tersebut disebut mati secara yuridis (hukmy) dengan diawali suatu dugaan terhadap penyebab kematian orang tersebut. Dan penyebab inilah yang disebut dengan mati karena dugaan keras (taqdiri) yang telah dipastikan dengan pembuktian dan melahirkan keputusan dalam bentuk mati secara yuridis (hukmy).

Oleh karena itu, orang yang dinyatakan meninggal dunia berdasarkan putusan Pengadilan dapat dipahami atau diterjemahkan kepada pengertian mati hukmi dan taqdiri, karena kedua syarat kematian tersebut, kebenarannya harus dinyatakan di hadapan pengadilan dengan memperlihatkan bukti-bukti yang dapat dijadikan dasar untuk mengambil keputusan hukum (hukmy).

Dari pembahasan tersebut, dapat disimpulkan bahwa kalimat "orang yang pada saat meninggal" termasuk kelompok orang yang meninggal secara hakiki ${ }^{11}$, yaitu tanpa adanya pembuktian secara hukum, semua orang bisa mengetahui bahwa orang tersebut meninggal dunia. Sedangkan pernyataan "yang dinyatakan meninggal berdasarkan putusan Pengadilan" adalah termasuk orang yang meninggal secara hukmy ${ }^{12}$ maupun taqdiri ${ }^{13}$ karena harus melalui pembuktian yang diyatakan dihadapan pengadilan.

\footnotetext{
${ }^{11}$ Kematian tanpa melalui pembuktian dapat diketahui dan dinyatakan bahwa seseorang telah meninggal dunia. Ahmad Rofiq, Fiqhi Mawaris (Cet. I; Jakarta: RajaGrafindo Persada, 1993), h. 22.

${ }^{12}$ Kematian secara yuridis melalui keputusan hakim dinyatakan telah meninggal dunia. Ini bisa terjadi seperti dalam kasus seseorang yang dinyatakan hilang (mafqud) tanpa diketahui dimana dan bagaimana keadaannya. Melalui keputusan hakim setelah melalui upaya-upaya tertentu, ia dinayatakan meninggal. Ibid.
} 
Walaupun syarat kematian dipersyaratkan pasal 171 huruf b Kompilasi Hukum Islam (KHI) terhadap seseorang dikatakan pewaris, namun dalam pasal yang lain membolehkan proses waris-mewarisi tanpa terjadinya kematian. Hal ini dapat dipahami pada rumusan pasal 187 ayat (1) sebagai berikut:

(1) Bilamana pewaris meninggalkan harta peninggalan, maka oleh pewaris semasa hidupnya atau oleh para ahli waris dapat ditunjuk beberapa orang sebagai pelaksana pembagian harta warisan dengan tugas:

a. mencatat dalam suatu daftar harta peninggalan, baik berupa benda bergerak maupun tidak bergerak yang kemudian disahkan oleh para ahli waris yang bersangkutan, bila perlu dinilai harganya dengan uang;

b. menghitung jumlah pengeluaran untuk kepentingan pewaris sesuai dengan pasal 175 ayat (1) sub a, b dan c. ${ }^{14}$

Pasal 187 ayat (l) memperkenalkan cara lain proses waris-mewarisi yang tidak pernah dirumuskan dalam kitab-kitab fikih kewarisan terdahulu. Kebolehan pelaksanaan waris-mewarisi tanpa didasari oleh adanya suatu kematian tidak mutlak pelaksanaannya. Hal ini dapat dipahami pada. Kata-kata "dapat" yang mengandung dua makna. Pertama, mengandung makna boleh melaksanakan waris-mewarisi tanpa didasari oleh adanya suatu kematian terhadap pewaris. Kedua, mengangdung makna tidak boleh melaksanakan waris-mewarisi tanpa didasari oleh adanya suatu kematian terhadap pewaris.

Kebolehan pelaksanaan waris-mewarisi tanpa didasari oleh adanya kematian terhadap pewaris, terkandung maksud untuk menghindari terjadinya perselisihan yang akhirnya terjadi kemudaratan di antara para ahli waris dalam pelaksanaan waris-mewarisi. Dengan masih hidupnya pewaris, maka perselisihan

\footnotetext{
${ }^{13}$ Kematian yang berdasarkan anggapan bahwa seseorang telah meninggal dunia. Misalnya karena ia ikut ke medan perang atau tujuan lain yang secara lahiriah mengancam dirinya. Setelah sekian tahun tidak diketahui kabar beritanya dan melahirkan dugaan kuat bahwa ia telah meninggal dunia, maka dapat dinyatakan bahwa ia telah meninggal. Ibid.

${ }^{14}$ H. Zainal Abidin Abubakar, op.cit., h. 351.
} 
harta warisan kemungkinan besar dapat diatasi oleh pemilik harta yang akan meninggal dunia (pewaris). Oleh karena itu, maka jalan satu-satunya adalah pelaksanaan waris-mewarisi harus dilaksanakan semasih pewaris masih hidup. Tetapi apabila tidak ada kemungkinan untuk berselisih terhadap harta yang akan ditinggalkan oleh pewaris, maka pelaksanaan waris-mewarisi harus dilaksanakan sesudah meninggalnya pewaris.

Kaitannya dengan pelaksanaan waris-mewarisi ada tiga hal dipersyaratkan Kompilasi Hukum Islam (KHI), sehingga benar-benar seseorang dapat dikatakan pewaris terhadap ahli warisnya yang beragama Islam.

\section{Beragama Islam}

Beragama Islam dipersyaratkan seseorang dikatakan sebagai pewaris, karena dikaitkan dengan objek atau sasaran pemberlakuan Kompilasi Hukum Islam (KHI), yaitu diperuntukkan kepada orang-orang yang beragama Islam dan lembaga Peradilan yang menangani masalah-masalah kewarisan umat Islam.

Kompilasi Hukum Islam (KHI) sebagai hukum materil yang diterapkan di Lembaga Peradilan Agama, harus mengacu kepada Undang-undang nomor 7 tahun 1989 tentang Peradilan Agama yang mengatur Kedudukan dan Kekuasaan Peradilan Agama. Pasal 2 Undang-undang nomor 7 tahlnn 1989 dijelaskan:

"Peradilan Agama merupakan salah satu pelaksana kekuasaan kehakiman bagi rakyat pencri keadilan yang beragama Islam. Mengenai perkara perdata tertentu yang diatur dalam Undang-undang ini. ${ }^{15}$

Perkara perdata tertentu yang dimaksud pada pasal 2 ini adalah seperti yang dijelaskan pada pasal 49 ayat (1) sebagai berikut:

\footnotetext{
${ }^{15}$ Ibid., h. 246.
} 
Pengadilan Agama bertugas dan berwenang memeriksa, memutus, dan menyelesaikan perkara di tingkat pertama antara orang-orang yang beragama Islam di bidang:

a. perkawinan;

b. waris;

c. wasiat;

d. hibah;

e. wakaf;

f. zakat;

g. infaq;

h. shadaqah; dan

i. ekonomi syari'ah. ${ }^{16}$

Mernahami dua pasal Undang-undang Republik Indonesia nomor 3 tahun 2006 tentang Perubahan Atas Undang-undang nomor 7 tahun 1989 tentang Peradilan Agama, dapat dikatakan bahwa Peradilan Agama hanya diperuntukkan kepada orang-orang yang beragama Islam dalam menyelesaikan persoalan perkawinan, kewarisan, wasiat, hibah, wakaf, zakat, infaq, shadaqah dan ekonomi syari'ah. Kesembilan persoalan tersebut telah diatur dalam Kompilasi Hukum Islam (KHI), termasuk persoalan waris-mewarsi.

Perumusan kembali adanya syarat beragama Islam terhadap orang yang mewariskan hartanya kepada ahli warisnya adalah merupakan penegasan terhadap adanya asas personalitas keislaman. Apabila orang yang mewariskan hartanya tidak beragama Islam, tentunya tidak dapat diberlakukan ketentuan hukum kewarisan yang berdasarkan ajaran Islam. Apabila orang yang mewariskan hartanya tidak beragama Islam, maka yang berwenang untuk memeriksa dan mengadilinya adalah Pengadilan Negeri.

3. Meninggalkan ahli waris

${ }^{16}$ Republik Indonesia, “Undang-undang R.I. Nomor 3 Tahun 2006 tentang Perubahan Atas Undang-undang Nomor 7 Tahun 1989 tentang Peradilan Agama (Jakarta: BP. Cipta Karya, 2006), h. 21-22. 
Syarat yang ketiga seseorang dikatakan pwaris apabila meninggalkan ahli waris. Hal ini sangat logis, karena proses waris-mewarisi dapat terjadi apabila ada yang menerima warisan. Tanpa ada ahli waris, maka harta peninggalan pewaris tidak dapat didistribusikan karena ahli warislah yang akan menerima harta peninggalan tersebut. Apabila orang yang mempunyai harta hidup tanpa ahli waris, maka harta peninggalannya atas putusan Pengadilan Agama diserhkan penguasaannya kepada Baitul Mal untuk kepentingan Agama Islamm dan kesejahteraan umum. Hal ini seperti diatur pada pasal 191 Kompilasi Hukum Islam bahwa:

Bila pewaris tidak meninggalkanahli waris sama sekali atau ahli warisnya tidak diketahui ada atau tidaknya, maka harta tersebut atas putusan Pengadilan Agama diserahkan penguasaannya kepada Baitul Mal untuk kepentingan Agama Islam dan kesejahteraan umum. ${ }^{17}$

4. Meninggalkan harta peninggalan

Harta peninggalan termasuk faktor utama terjadinya proses waris-mewarisi antara pewaris dengan ahli waris. Tanpa ada harta peninggalan proses warismewarisi tidak bisa dilaksanakan, karena harta peninggalanlah yang menjadi atau yang akan diwarisi oleh para ahli waris. Harta peninggalan orang meninggal dunia diatur pada pasal 171 huruf d "harta peninggalan adalah harta yang ditinggalkan oleh pewaris baik yang berupa benda yang menjadi miliknya maupun hakhaknya"18 dan harta warisan diatur pada pasal 171 huruf e "harta waris adalah harta bawaan ditambah bagian dari harta bersama setelah digunakan untuk

\footnotetext{
${ }^{17}$ H. Zainal Abidin Abubakar, op.cit., h. 352

${ }^{18}$ Ibid., h. 348.
} 
keperluan pewaris selama sakit sampai meninggalnya, biaya pengurusan jenazah (tajhiz), pembayaran hutang dan pemberian untuk kerabat." ${ }^{\prime 19}$

\section{KESIMPULAN}

Dari uraian tersebut di atas, maka dapat ditarik kesimpulan sebagai berikut:

1. Orang yang mewariskan hartanya harus memenuhi syarat-syarat sebagai berikut:
a. Telah meninggal dunia dunia atau dinyatakan meninggal dunia;
b. Beragama Islam;
c. Meninggalkan ahli waris;
d. Meninggalkan harta warisan.

2. Bentuk-bentuk kematian orang yang mewariskan hartanya adalah:
a. Kematian secara hakiki;
b. Kematian secara hukmy;
c. Kematian secara taqdiri;

3. Orang yang mewariskan hartanya dan tidak meninggalkan ahli waris sama sekali atau ahli warisnya tidak diketahui ada atau tidaknya, maka harta peninggalannya tersebut atas putusan Pengadilan Agama diserahkan penguasaannya kepada Baitul Mal untuk kepentingan Agama Islam dan kesejahteraan umum.

\footnotetext{
${ }^{19}$ lbid.
} 


\section{DAFTAR PUSTAKA}

Abubakar, Zainal Abidin, Kumpulan Peraturan Perundang-undangan Dalam Lingkungan Peradilan Agama (Cet. III; Jakarta: Yayasan Al-Hikmah, 1993).

Arto, Mukti, Hukum Kewarisan Bilateral Dalam Kompilasi Hukum Islam (Cet. I; Solo: Balqis Queen, 2009).

Departemen Agama R.I., Al-Qur'an dan Terjemahnya (Jakarta: Yayasan Penyelenggara Penterjemah Al-Qur'an, 1983/1984).

Djakfar, Idris dan Taufik Yahya, Kompilasi Hukum Kewarisan Islam (Cet. I; Jakarta: PT. Dunia Pustaka Jaya, 1995).

Imam Abi al-Husain Muslim ibn al-Hajjaj al-Qusyairy al-Naisabury, Shahih Muslim, Juz. III, (Beirut: Dar al-Kutb al-'Ilmiyyah, t.th.).

Imam Abi al-Husain Muslim ibn al-Hajjaj al-Qusyairy al-Naisabury, Shahih Muslim, dalam Hadith Ensiklopedi Hadits ver. 1.2 [CD ROM], Lidwa Pusaka, 2010.

Moh. Muhibbin dan H. Abdul Wahid, Hukum Kewarisan Islam: Sebagai Pembaruan Hukum Positif di Indonesia (Cet. I; Jakarta: Sinar Grafika, 2009).

Rahman, Fatchur, Ilmu Waris (Cet. III; Bandung: PT. Al-Ma'arif, 1994).

Rofiq, Ahmad, Fiqh Mawaris (Cet. I; Jakarta: PT. RajaGrafindo, 1993).

Syarifuddin, Amir, "Kedudukan Anak laki-laki dan Anak Perempuan dalam Hukum Kewarisan”, Majalah Orientasi Nomor 2 Tahun VIII. Banjarmasin: Lembaga Perpustakaan/Penerbit Fakultas Hukum Universitas Lambung Mangkurat.

Republik Indonesia, "Undang-undang R.I. Nomor 3 Tahun 2006 tentang Perubahan Atas Undang-undang Nomor 7 Tahun 1989 tentang Peradilan Agama (Jakarta: BP. Cipta Karya, 2006), h. 21-22. 